\title{
Voldstederne på de nordfrisiske øer
}

\author{
af Ole Harck
}

På Sild og Før ligger der flere storslåede ringvolde og en del mindre »voldsteder«. Først i de seneste år har grundige undersøgelser givet et solidt videnskabeligt grundlag for at tolke og datere disse anlæg. Dr. Ole Harck, Egernførde, giver her et resumé af den nyeste viden om anlæggene - en viden, som på mange måder bryder med hidtil gængse skildringer af emnet.

Af en eller anden ukendt grund har den regionale historieforskning altid fremhævet, at ringborgene på Sild og Før, Arksumborg, Tinnumborg og Lembecksborg, hørte til gruppen af ældre forsvarsanlæg i Vestslesvig, og det på trods af, at en egentlig målbevidst arkæologisk udgravningsvirksomhed $\mathrm{i}$ disse anlæg først blev påbegyndt efter 2 . verdenskrigs afslutning. Den videnskabelige litteratur om Sønderjyllands ældre middelalderhistorie er derudover ret enig om at datere voldstederne til omkring år $800 \mathrm{og}$ at tolke dem som "tilflugtsborge for befolkningen under urotider" eller som "militærstationer" svarende til de velkendte, men noget senere danske Trelleborge. ${ }^{1}$ Denne tolkning beror især på fund fra Lembecksborg på Før, som P. La Baume og H. Jankuhn gravede i mellem 1946 og 1952. Derimod har undersøgelser siden 1972 i Arksumborg og Tinnumborg på Sild endnu ikke vundet den fornødne genklang i den interesserede offentlighed, til trods for at udgravningernes resultater er beskrevet flere steder inden for de seneste år. ${ }^{2}$

På baggrund af den nye viden om de sidstnævnte ringvolde er det imidlertid muligt at genanalysere ældre oplysninger om andre »forsvarsværker« på øerne ud for den sønderjyske vestkyst. Det gælder både med hensyn til deres topografiske placering i terrænet, det foreliggende arkæologiske materiale og den formodede historiske betydning set $\mathrm{i}$ relation til lignende anlæg på fastlandet (fig. 1).

\section{Jernalderens ringvolde}

Lembecksborg på Før (fig. 1, nr. 6) og Tinnumborg på Sild (fig. 1, nr. 2) er de største arkæologiske monumenter på de nordfrisiske øer. Begge anlægs meterhøje volde fremstår som markante jordværker ragende op i det ubebygge- 


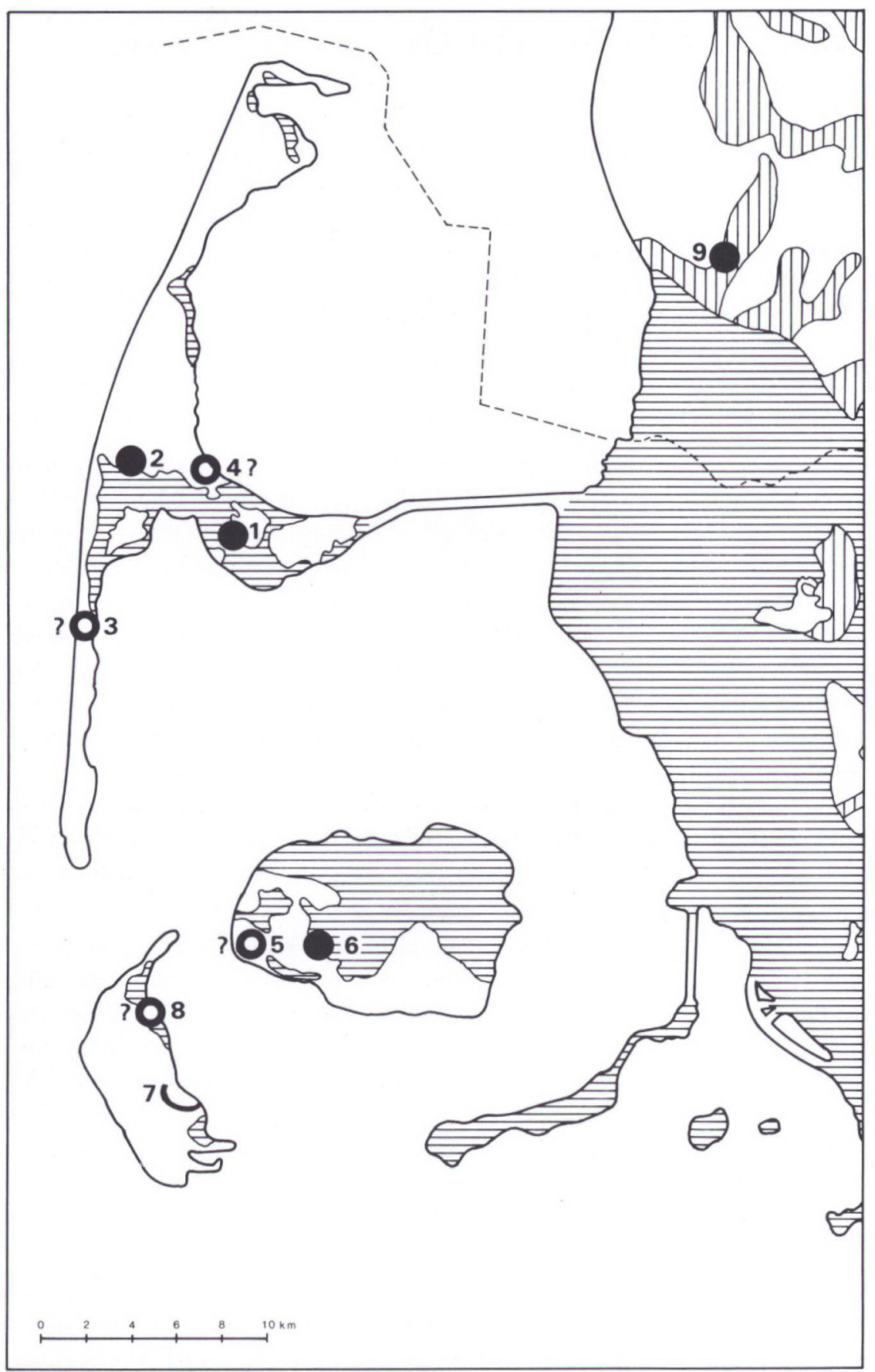


de flade marskland (fig. 2). Heroverfor lå så Arksumborgs tomt på Sild nærmest gemt bag byhøjbanker fra jernalder og middelalder på en lav gestryg over marskens niveau (fig. 1, nr. 1). Vore dages ihærdige byggespekulanter har dog formået at ødelægge det særprægede relief på denne mindste af Silds bakkeøer. ${ }^{3}$ De tre ringformede anlæg er nærmest ens topografisk placeret $\mathrm{i}$ overgangszonen mellem gest og marsk eller ude i selve marsken og uden nogen direkte forbindelse til havet. Meget kunne derfor tyde på, at der er fælles baggrund for deres opførelse.

I årene efter krigen og især siden 1972 er der gravet $\mathrm{i}$ ringvoldene både på Sild og på Før. Mens lagfølgen i Tinnumborg kun kunne analyseres i enkelte snit i ringvoldens nordlige del, så beror kendskabet til Lembecksborgs opbygning på flere fladeafdækninger bag volden. Arksumborgs vestlige halvdel blev stort set udgravet mellem 1972 og 1978 inden for et større forskningsprojekts rammer, som instituttet for forhistorisk arkæologi ved Kiels universitet startede i 1963 med støtte fra bl.a. Deutsche Forschungsgemeinschaft, Bonn-Bad Godesberg. Undersøgelsens resultater bruges af nærliggende grunde som indledning til den efterfølgende fremstilling af det arkæologiske materiale fra Nordfrislands voldsteder.

Arksumborgs $2,5 \mathrm{~m}$ høje tomt ligger på den let skrånende søndre del af bakkeøen, et par hundrede meter fra den centralt på gesten placerede landsbykærne med bebyggelsesspor fra vikingetid og middelalder. ${ }^{4}$ Borgbanken, der i det oprindelige frisiske folkemål kaldes for »Borig«, måler $105 \mathrm{~m}$ fra nord til syd og $120 \mathrm{~m}$ fra øst til vest, jordpåfyldninger $\mathrm{i}$ middelalderen og nyere tid har forøget det sidstnævnte tværmål betydeligt. Svage spor af voldens krone kunne kun anes i terrænet, inden området blev bebygget i slutningen af 70erne. De historiske kilders oplysninger om Arksumborg er fă: Volden nævnes første gang i Hans Kielholts noget diffuse krønike fra 1400-tallet, ${ }^{5}$ den tidligste sikre henvisning findes i J. Mejers kort over Sild fra 1652, hvor Arksumborg er indtegnet som voldsted. ${ }^{6}$ Den følgende tids skriftlige optegnelser synes nærmest modstridende med hensyn til spørgsmålet om, hvorvidt voldkronen i sin helhed eller kun $i$ visse afsnit har været synlig inden bankens endelige planering senest i 1860. I denne sammenhæng får et matrikelkort fra 1780 afgørende betydning, idet de dengang opmålte flader fulgte den ved de senere arkæologiske undersøgelser dokumenterede volds ydre front, selv om udgravningerne har givet belæg for voldens destruktion og det indre områdes planering i ældre romersk jernalder. ${ }^{7}$

Fig. 1. Kort over de i artiklen navnte lokaliteter: 1. Arksumborg; 2. Tinnumborg; 3. Rantumborg; 4. "Tipkenhern" ved Kejtum; 5. »Borreg" ved Utersum; 6. Lembecksborg; 7. "Krümwal" ved Nebel; 8. "Boraghw ved Norddorf; 9. "Tralbanken" ved Kargdird. 

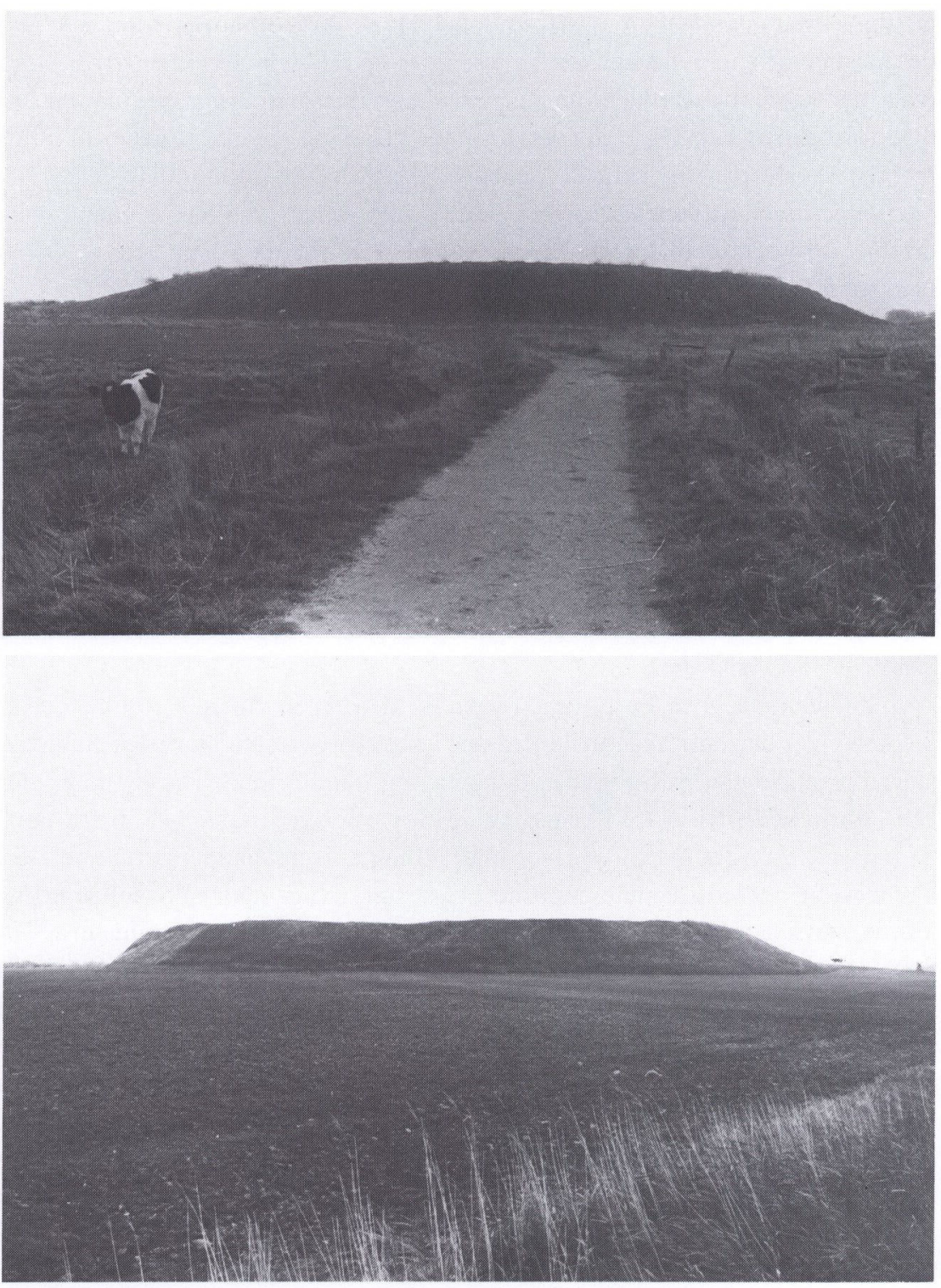

Fig. 2. Foroven: Tinnumborg på Sild; forneden: Lembecksborg på For.

Botaniske analyser af konserverede, uberørte jordlag under det ældste jordværk viste, at arealet forud for ringvoldens rejsning lå hen som ødemark til trods for en samtidig større bondebebyggelse lige i nærheden. ${ }^{8}$ Den primære, ca. en meter høje græstørvsvold målte i basis omkring $5 \mathrm{~m}$, dens form syntes 
nærmest at have været cirkulær med et indre tværmål på omkring $64 \mathrm{~m}$. Senere, dvs. før der kunne dannes en fast grønsvær på voldoverfladen, eller denne var blevet angrebet af regn og vejrlig, har man både forhøjet og udvidet voldkærnen med flere lag af græs- og klægtørv. Det er lykkedes at definere 24 enkelte voldfaser over det ældste anlæg og ved at inddrage resterne af forskellige byggeaktiviteter inden for den aldste vold i det stratigrafiske system (ca. $30 \mathrm{lag}$ ) at kunne sammenfatte de enkelte bebyggelsesspor i fem eller seks større hovedafsnit.

Efter den seneste udvidelse ved voldens indre fod viste jordværket en bredde på omkring $10 \mathrm{~m}$, mens højden åbenbart varierede mellem to og tre meter målt over det oprindelige niveau. På dette tidspunkt havde jernalderbønderne dog allerede skrånet en tidligere lodret voldfront med meterhøje klæg- og muldlag, hvorefter en tolkning af anlægget enten som forsvarsværk eller som sikring mod højvande synes tvivlsom.

Indgangen til det af volden begrænsede areal lå $\mathrm{i}$ anlæggets nordlige del: Den aldste vold var ikke helt lukket på et par meters længde; senere opførtes samme sted en $6 \mathrm{~m}$ lang, $1 \mathrm{~m}$ bred stolpestøttet passage med spor af flere ombyggelsesfaser. Gennemgangens placering i volden blev markeret med klægtørvsvægge både uden for $\mathrm{og}$ inden for selve volden. I en af de seneste perioder byggedes så her en ca. $10 \mathrm{~m}$ lang, $1 \mathrm{~m}$ bred krybegang af kampesten oven i resterne af de tidligere perioders indgange (fig. 3a). Som led i dette bygningsværks rejsning fyldte man dog passagen med rent klæg, inden den blev tildækket med flade stenblokke.

Samtidig med disse byggeaktiviteter på volden ( 25 faser) og omkring den nordvendte indgang (mindst 7 faser) blev der $\mathrm{i}$ anlæggets ældre tid rejst flere letkonstruerede hytter med fletværks- eller græstørvsvægge langs voldens indre fod. De to- eller treskibede bygninger stod i radiær anordning med en af smalsiderne vendt mod voldstedets geometriske centrum, der var ubebygget. Hytterne målte i bredden mellem 2,1 og $4 \mathrm{~m}$, mens længden varierede mellem 4 og $8 \mathrm{~m}$, flademålet skiftede derved mellem 8,4 og $32 \mathrm{~m}^{2}$. På gulvfladerne i hytterne fandtes flere steder et tyndt lag strøelse, desuden i enkelte af småhusene lerklinede arner (fig. 3b). I modsætning til samtidige bopladsfund lykkedes det ikke at fastslå rester af korn eller anden vegetabilsk føde inden for disse bygningsspor. Uden for hytterne fandtes et større antal af stolper med ukendt funktion, et stykke af et træhegn og et par ildsteder, som ikke kunne placeres i forhold til bestemte hytterester. Intet sted gav fundmaterialet belæg for, at mennesker eller dyr havde haft tilgang til området inden for volden mellem de enkelte byggeafsnit (fig. 4).

Hyttebebyggelsen hørte til Arksumborgs aldste perioder. Fra den efterfølgende tid kendes derimod til et par brøndlignende, flere meter dybe skakter 
inden for volden. Disse nedgravninger $\mathrm{i}$ istidens mergellag blev delvis fyldt med jord og sten, inden siderne nåede at skride sammen som følge af grundvandets tryk. Senere forsynedes $i$ hvert fald to af de tre undersøgte skaktanlæg med en hyttelignende afdækning.

Fundmaterialet fra Arksumborg består fortrinsvis af keramik, f.eks. skår af forskellige lerkar, skåle, kopper og ildbuklignende krukker med hank. Dette lertøj genspejler både i sin kvantitative og kvalitative sammensætning et samtidigt bopladsinventar. Derudover fandtes der bl.a. følgende keramikgenstande, der åbenbart var importerede til Sild udefra: Skår af nordhollandsk "terpekeramik «, låg med hanke af nedresaksisk-vestfrisisk type ${ }^{9}$ og trekantede vævevægte af en især vest for floden Weser, i Holland og England udbredt form. ${ }^{10}$ Det walmindelige « skårmateriale - ca. 7500 stykker - lå fortrinsvis i den bebyggede zone omkring de omtalte hytter langs voldens fod. Samtlige lerkarskår viser gennemgående en ringere brudfrekvens end den kendes fra de samtidige bondesamfunds bopladser. Dette særpræg peger på et hurtigt bebyggelsesskift inden for volden uden større skårødelæggende aktiviteter. Samtlige oldsager dateres til midten af 1 . århundrede efter Kristi fødsel, dvs. til ældre romertid. Der kan ikke dokumenteres nogen form for udvikling i lerkarsproduktionen på grundlag af skårmaterialet fra de ældste og de yngste lag. Dette er tolket som belæg for, at bebyggelsen i Arksumborg har været af kort varighed.

Udover de nævnte importfund af vesteuropæisk herkomst er det også lykkedes at føre bevis for forbindelserne til den senkeltisk/romersk dominerede region omkring den Engelske Kanal på grundlag af særprægede træk i bygningernes konstruktion og $\mathrm{i}$ voldanlæggets samlede plan og idémæssige grundlag. ${ }^{11}$ Heroverfor står så, at de eneste sikre paralleller til den nordvendte krybegang tværs igennem jordværket skal søges i gruppen af såkaldte »stenkældre $i$ Vendsyssel fra perioden omkring Kristi fødsel. ${ }^{12}$

De nævnte og mange andre, ikke omtalte argumenter førte til at tolke Arksumborg som kultplads, hvor man som del af den rituelle handling kopierede et mindre samfund, en uvirkelig bebyggelse eller en slags Potemkinsk landsby, til ukendte guders are. Hvorvidt keramikken $\mathrm{i}$ hytterne for $\mathrm{i}$ tiden indeholdt offergaver til de hinsides magter vides ikke. Knoglefund, der bl.a. karakteriserer samtidige jyske offerpladser, mangler stort set; belæg for detaljerne i selve offerproceduren inden for voldens afgrænsede område er ukendte.

Kort efter den seneste udvidelse af volden - dvs. sandsynligvis engang $i$ løbet af ældre romersk jernalder - blev borgbanken planeret. Der fandtes ingen spor af en senere tids bebyggelse - hverken fra vikingetid eller middelalder.

Ringformede voldanlæg af Arksumborg-typen kendes med sikkerhed på fast- 
landet ved Højer (fig. 1, nr. 9), hvor Trælbankens opbygning og datering svarer til Arksumborgs. ${ }^{13}$ Hvorvidt et nyfundet cirkulært voldsted ved Vilslev i nærheden af Ribe også hører til denne gruppe, vides endnu ikke, ${ }^{14}$ derimod er der ingen tvivl om, at der ligger en ringvold svarende til Arksumborganlægget under vikingetidens Tinnumborg på Sild.

Den sidstnævnte velbevarede 5-6 m høje ringvold af oval form $(125 \times 110$ m) ligger ude i marsken, kun $5 \mathrm{~km}$ i luftlinie vest for Arksumborg. ${ }^{15}$ Nogle vikingetidsskår, der blev fundet under en ikke fuldført udgravning i 1948, daterede bl.a. en græstørvsvæg og en stenbrolægning til det 9.-10. århundrede efter Kristus. I 1976 lykkedes det $i$ en ny søgegrøft $i$ den nordlige voldside både at dokumentere de indvendige lags stratigrafi fra istidens overflade til de seneste voldudvidelser og ved et snit ind i ringvoldens ydre side at få indblik i nogle af voldfasernes forskelligartede konsistens. Et tværgående profil igennem Tinnumborg lå desværre uden for projektets økonomiske og arbejdstekniske muligheder. Resultaterne af den kortvarige undersøgelse i Tinnumborg har derfor kun foreløbig karakter: Den ældste vold under vore dages monument blev lagt i ældre romertid på klægsediment fra tidlig førromersk jernalder. Mens selve volden ikke kunne bestemmes med sikkerhed, lykkedes det at finde et inden for denne liggende kulturlag med daterende keramik. Voldens eksistens beror på et indirekte bevis: Over kulturlaget fra ældre romertid fulgte et mægtigt sumptørvelag mellem 1,5 og $1,75 \mathrm{~m} \mathrm{NN}$, dvs. omkring $0,8 \mathrm{~m}$ over den uden for volden liggende marsk's niveau. De i tørvemassen dokumenterede rørsumpplanter vokser tilmed kun under vedvarende fugtighed. Udfra lokalitetens topografiske situation ville dette kun have været muligt $i$ forbindelse med f.eks. en aflukket klægtørvsvold af ukendt diameter, højde og konsistens.

Også under Lembecksborgs ringvold fra vikingetiden lå der skår fra ældre romertid. ${ }^{16}$ Her er det dog ikke med sikkerhed lykkedes at dokumentere den samtidige vold. Udgravningerne i årene efter 2 . verdenskrigs afslutning gav udelukkende klarhed over, at skårene lå i de »dybere lag«.

I modsætning til Arksumborg udbyggedes både Tinnumborg og Lembecksborg som "regulære« voldsteder i vikingetid: Førstnævnte sted fandtes under udgravningerne i 1976 flere græstørvsvægge parallelt med volden eller lodret ind mod denne, et enkelt ildsted og flere kontaktlag mellem disse bygningsrester og voldens græstørvfyld. Fund fra de over sumptørvelaget stratificerede kulturlag, bl.a. lerkarskår, stykker af klæberstenskar og flere velbevarede træredskaber, heriblandt dele af en tallerken, et sidestykke til et større kar, et knivskaft og forskellige nagler, daterer den yngre vold til det 8.-10. århundrede.

Lembecksborgs vold er nærmest cirkulær ifølge de publicerede opmålinger, mens den efter beskrivelserne at dømme, f.eks. hos P. La Baume, snarere 

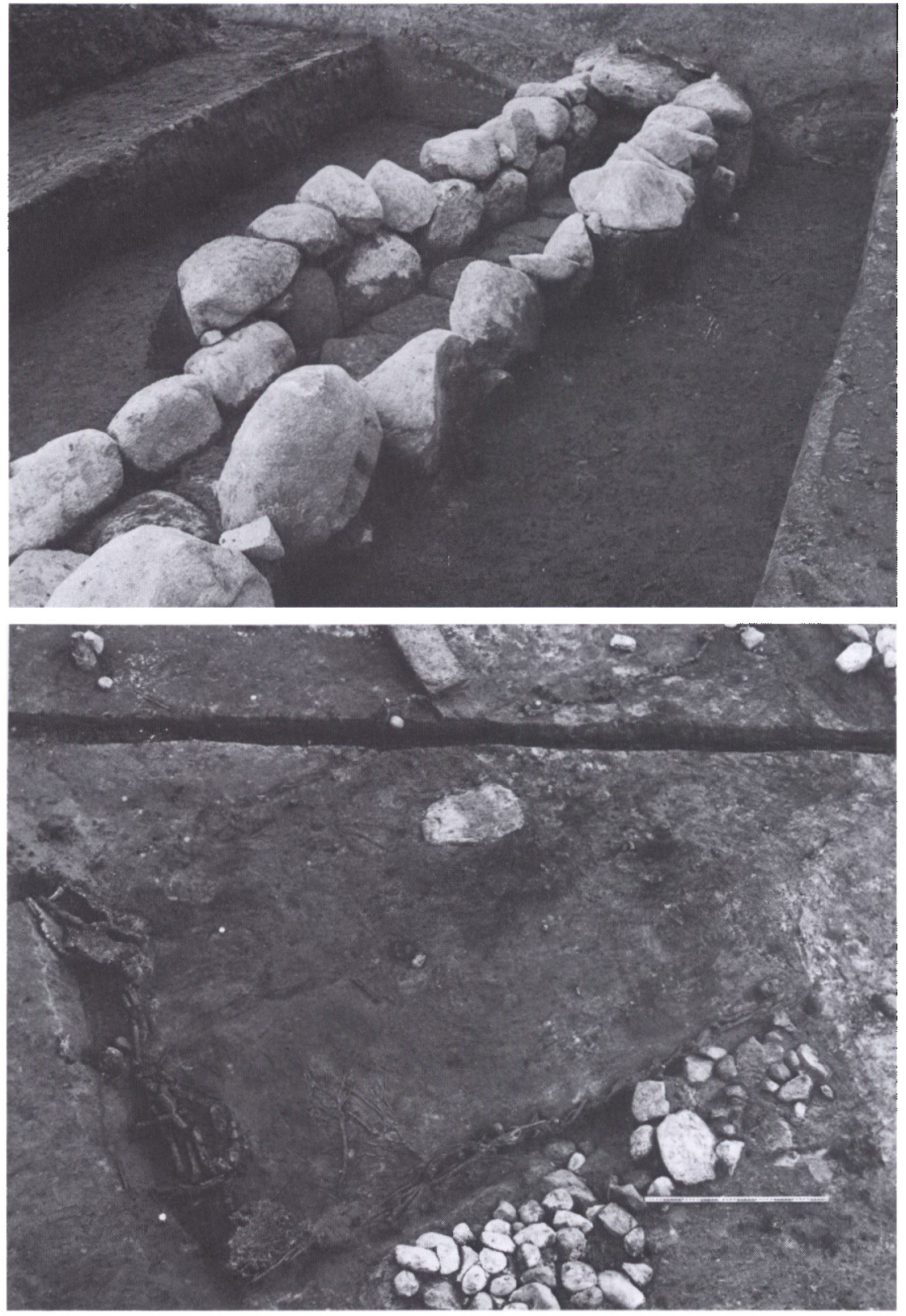

Fig. 3. Arksumborg/Sild. Foroven: Krybegang tvars igennem volden. I profilvaggen bagved ses en af de store stenblokke, der brugtes til afdakning af passagen. Forneden: Hytte med fletvarksvagge fra aldre romertid (1. drhundrede efter Kristi fodsel). Den lyse plet midt $i$ billedet viser et lerklinet ildsted. Voldens indre fod er synlig til venstre. 
skulle være ovalformet med et tværmål på $120 \times 100 \mathrm{~m}$. Voldens krone ligger ca. $10 \mathrm{~m}$, det indre område omkring $4 \mathrm{~m}$ over marskens niveau. Udgravninger inden for volden gav enkelte henvisninger til vikingetidsbebyggelsens struktur, bl.a. forskellige huse, der nærmest var radiært placerede langs voldens fod, og dele af brolagte veje mellem disse bygninger, men ingen oplysninger om selve voldens konstruktion, om kontaktlag mellem vold og udgravede vægrester. Et utal af fund fra vikingetid (keramik, brudstykker af klæberstenskar og basaltmøller, flere smykker af metal) daterer anlægget ifølge La Baume til det 9.-10. århundrede og tiden omkring år $1000 .{ }^{17} \mathrm{H}$. Jankuhn synes $\mathrm{i}$ en mere historisk tolkning af anlægget at være i tvivl om, hvorvidt Lembecksborg har haft en permanent bosætning eller kun har været brugt som tilflugtsborg $i$ ufredstider. ${ }^{18}$ Dette spørgsmål og problemerne omkring en sikker naturvidenskabelig funderet tidsbestemmelse vil kun kunne løses i forbindelse med en større udgravning i fremtiden.

En gennemgang af det forhåndenværende skårmateriale på baggrund af nyere undersøgelser i Slesvig, Elisenhof ved Tønning, Ribe og Århus ville muligvis i første omgang føre til en omdatering af enkelte lerkar fra Tinnumborg og Lembecksborg. ${ }^{19}$ Et par af skårene bør efter alt at dømme tidsfæstes til efter årtusindskiftet, hvormed vi når frem til den periode af tidlig middelalder, som vi har et bedre kendskab til. De foreliggende arkæologiske fund udelukker dog med stor sikkerhed en kontinuitet mellem Tinnumborgs yngste fase og oprettelsen af en fogedstilling $\mathrm{i}$ landsbyen Tinnum på gesten nordøst for volden og mellem Lembecksborgs seneste bebyggelse og ridder Klaus Limbecks gøremål på Før, Sild og Amrum omkring 1360, selv om det sidstnævnte voldsted har navn efter denne kong Valdemar Atterdags mand.

\section{Middelalderlige "tårnborge« og "voldsteder«}

Ud over de ringformede voldanlæg af vidt forskellig funktion fra ældre romertid og vikingetid findes der flere lokaliteter på de tre nordfrisiske hovedøer, som i tidens løb er blevet tydet som forsvarsværker. ${ }^{20}$ Arkæologiske udgravninger og en sikker historisk overlevering mangler, medens der er en del tvivlsomme stednavnehenvisninger og sagn i tilknytning til bestemte terrænspor eller særlig markante ældre gravhøje. På Før ligger "Borreg" ca. $400 \mathrm{~m}$ nordvest for landsbyen Utersum $i$ et sumpet dalstrøg (fig. 1, nr. 5). ${ }^{21}$ Omkring 1900 havde banken - ifølge en samtidig beskrivelse - en højde på ca. $4 \mathrm{~m}$ og et tværmål på ca. $30 \mathrm{~m}$. Ved en senere planering fandtes her teglsten, jernstykker og noget trækul. Udenom lå der tidligere både en vold, som indeholdt træstykker fra et palisadehegn (?), og en $6 \mathrm{~m}$ bred grav. H. Jankuhn beskrev i 1954 
"borgens" topografi og diskuterede $\mathrm{i}$ denne sammenhæng kartografiske og historiske kilder. ${ }^{22}$ Til de sidstnævnte hører bl.a. en i 1845 nedskrevet beretning om en møntskat fra det 11. århundrede, som lå gemt under en træpæl i selve "Borreg«-banken. Til trods for usikkerhed om møntdeponeringens nøjagtige placering på stedet brugte Jankuhn denne oplysning $\mathrm{i}$ argumentationen for at betegne "Borreg" som en tidlig tårnborg. Senere har H. Hinz dog i en undersøgelse af samtlige nord- og vesteuropæiske tårnborge fremført berettiget kritik af denne sammenblanding, idet borgtypen først kendes nord for Elben i løbet af det 13. århundrede. ${ }^{23}$

Silds »tårnborg«, Tipkenhörn på Kejtum klev i nærheden af landsbyens tidligere havneplads, men langt fra middelalderens kirke og den hertilhørende bondebebyggelse (fig. 1, nr. 4), blev undersøgt af arkæologer i 1870, 1940 og 1955. Samtlige udgravninger fik et negativt resultat til folge, idet der fremdroges skår af broncealderkeramik, men ingen belæg for en senere tids aktivitet eller bebyggelse. ${ }^{24}$ En tilsvarende situation synes at foreligge i forbindelse med stedbetegnelsen "Boragh « på Amrum (fig. 1, nr. 8). Det arkæologiske materiale består af et par opsamlede skår, der enten stammer fra vikingetid/tidlig middelalder eller nyere tid (!). "Borgbanken« på et østvendt klev ud mod vadehavet mellem Amrum og Før var ifølge overleveringen oprindelig en broncealderhøj omgivet af en jordvold (?) og en uden om denne liggende grav (?). De sidstnævnte rester var nærmest planerede, da stedet blev beskrevet for første gang i $1869 .{ }^{25}$

Hverken i Kejtum eller i Norddorf på Amrum er der noget belæg for en middelalderlig tårnborg, på samme måde synes de fremførte argumenter $\mathrm{i}$ forbindelse med Utersum-anlægget at være mere end tvivlsomme. Over for dette negative resultat står så en oplysning $\mathrm{i}$ en af A.L.J. Michelsen trykt kilde, hvor det nævnes, at Erik Rind - bror til Valdemar Atterdags staller i Nordfrisland, Valdemar Zappi - var blevet borgherre på Før. ${ }^{26}$ Det meddeles i denne sammenhæng, at borgen inklusive den tilhørende ladegård har ligget mellem Utersum og Borgsum, hvormed den ikke kan være identisk med det førnævinte anlæg nordvest for Utersum, og at der er tale om et nyopført "castellum«. Overtagelsen af godset kan dateres til den første søndag efter allehelgen 1360, kontrakten er beseglet af præsterne ved øens kirker, St. Johannes, St. Nikolaj og St. Laurentius. Ud fra disse enkeltheder om »borgen" mente f.eks. H. Handelmann i 1873, at hele anlægget kun har bestået af et "blokhus", der var omgivet af en vold og et palisadehegn.

I denne forbindelse bør det påpeges, at Erik Rind - og sammen med ham broderen Valdemar Zappi eller Soep, som han kaldes andetsteds - kom til de nordfrisiske øer som fremmede adelsfolk, der var udsendt af kongen. Intet sted findes der oplysninger om ældre høvdingeslægter, en lokal lavadel eller 
fremtrædende storbønder. Deres tilstedeværelse ville have været en forudsætning for rejsning af tårnborge $\mathrm{i}$ hvert fald $\mathrm{i}$ en senere del af middelalderen. ${ }^{27}$ Denne viden understreger den fremførte usikkerhed om, hvorvidt den slags anlæg overhovedet har eksisteret på Sild, Før og Amrum. De engelske møntfund fra tiden efter årtusindskiftet i List (976-1029), Vesterland (1. halvdel af det 11. århundrede) og Utersum (11. århundrede) er tolket som Danefæskatte, der skulle gemmes bort - langt fra datidens bebyggelse - og siden blev glemt. Deponeringerne har intet med de lokale bondesamfund og deres sociale struktur at gøre. ${ }^{28}$

Hvorvidt "Rantumborg" på Sild har været et ringformet voldsted eller en tårnborg vides ikke (fig. 1, nr. 3).$^{29}$ En øjenvidneberetning fra omkring 1800 henviser bare til en "græsbevokset (!) jordvold«. Ifølge overleveringen skjulte den sig under klitsand $i$ et område syd for landsbyen Rantum kaldet "Burgtal" eller »Borig«. I H. du Plat's kort fra 1804/05 findes henvisningen »Borgrudera" ud for denne klitdel. Hvis de sparsomme oplysninger om selve monumentet og stednavnets placering holder stik, så måtte anlægget efter de nyeste geologiske analyser at dømme have ligget $i$ en istidslavning fyldt med holocæne strandsedimenter eller flyvesand, idet den faste undergrund her ikke når over minus 4-5 $\mathrm{m}$ under vore dages overflade. ${ }^{30}$ Denne sammenhang understreger derfor tvivlen omkring dette i ø-litteraturen tit omtalte monument. En datering synes umulig på det foreliggende grundlag.

Samme spørgsmålstegn med hensyn til tidsfæstelsen gælder for "Krümwal" på Amrum (fig. 1, nr. 7). Dette $1400 \mathrm{~m}$ lange, halvkredsformede dige afgrænsede et større bakkedrag sydøst for Amrums kirkeby Nebel. Efter K. Kerstens beskrivelse viser volden enkelte steder en bredde på $8,5-11 \mathrm{~m}$, mens højden varierer mellem 1,10 og $1,80 \mathrm{~m}^{31}$ Nyere undersøgelser $\mathrm{i}$ volden, der kunne bidrage med detaljer om opbygning, stratigrafi osv. mangler bortset fra et enkelt resultatløst snit. Derfor er det indtil videre umuligt at sætte volden i relation f.eks. til de kendte »folkevolde« fra jernalderen eller folkevandringstiden, som Olgersdiget ved Tinglev, Danevirke og Trældiget ved Vejle. ${ }^{32}$

\section{Sammenfatning - nye resultater}

Gennemgangen af de enkelte voldsteders arkæologiske materiale og de historiske kilders mere eller mindre sikre baggrund, de forskellige lokaliteters topografi og datering viser først og fremmest, hvorledes arkæologiske undersøgelser inden for en kort årrække kan revidere tidligere historieforskning på forskellige punkter. I dag kender vi til følgende voldtyper på de nordfrisiske øer:

1. Oldtidsborgene: Arksumborg og muligvis også Tinnumborg, begge på 
Sild, opførtes omkring midten af det 1. århundrede efter Kristi fødsel som kultsteder. Førstnævnte anlæg viste en tydelig vesteuropæisk, dvs. senkeltisk indflydelse $\mathrm{i}$ konception, bebyggelsesstruktur og fundmateriale, mens andre detaljer tydeliggør forbindelser med fundkomplekser i Nordjylland.

2. Vikingetidsborgene: Tinnumborg/Sild (2. periode) og Lembecksborg/Før dateres af talrige fund til det 9.-10. århundrede. Enkelte af skårene tilhører muligvis en senere tid. De sparsomme oplysninger om selve bebyggelsen inden for volden giver intet grundlag for besvarelsen af spørgsmålet vedrørende bosætningskontinuitet eller sporadisk bebyggelse for den lokale bondebefolkning - f.eks. i ufredstider -, eller om forbindelser til samtidige voldsteder $i$ Vestholsten, Hamborg eller Nedresaksen. Det er dog sikkert, at ingen af voldene kan tilregnes Trelleborg-typen på grund af en manglende symmetri $\mathrm{i}$ bygningsplanen og voldens form. Der synes ikke at være nogen sammenhæng mellem de yngste voldlag og de senere århundreders lokale middelalderhistorie (fogeden i Tinnum og Klaus Limbeck på Før). Borgenes historiske betydning er dermed stadigvæk en gåde.

3. Middelalderens »anlæg«: Henvisningerne til formodede tårnborge, lavadelens karakteristiske forsvarsværker $i$ det 13.-14. århundrede, er mere end tvivlsomme på Sild, Før og Amrum. En kilde fra 1360 nævner en befæstet gård af hel anden type på Før, der ikke er identisk med en nærliggende "tårnborg«. Ingen af de omtalte "tårnborgs-banker « lå tilmed i nærheden af datidens naturhavne, som J. Mejer kaldte for "wyck« i de ældste pålidelige kort fra 1652. Hermed bortfalder disse steders strategiske funktion og deres værdi som forsvarsværker.

Problemerne omkring voldstederne på de tre nordfrisiske øer er langtfra afklarede endnu. En ting er dog sikker: Både oldtidens ringvolde og vikingetidens forsvarsværker - middelalderens "stårnborge« kan man vist se bort fra synes at være noget helt specielt ved den slesvigske vestkyst, idet de nævnte jordværker indtil videre ikke har nogen paralleller hverken på midtryggen langs den sønderjyske Hærvej eller i den frugtbare østlige ungmoræne. Vort igennem de skriftlige kilder dokumenterede kendskab til regionens tidligste historie er generelt ringe - også set i relation til det arkæologiske materiale. Oldtidens fund viser f.eks. snævre handelsforbindelser i kyststrøget mellem den Engelske Kanal og Sild $i$ hele romersk jernalder, i vikingetid åbnedes tilgangen til kystzonen bl.a. via havnene i Hamborg, Meldorf, ved Ejdermundingen og omkring Ribe å. Talrige fund af denne tids mønter og af importeret

Fig. 4. Arksumborg/Sild. Hyttespor fra aldre romertid langs voldens indre fod. Anlaggets centrum var ubebygget. 


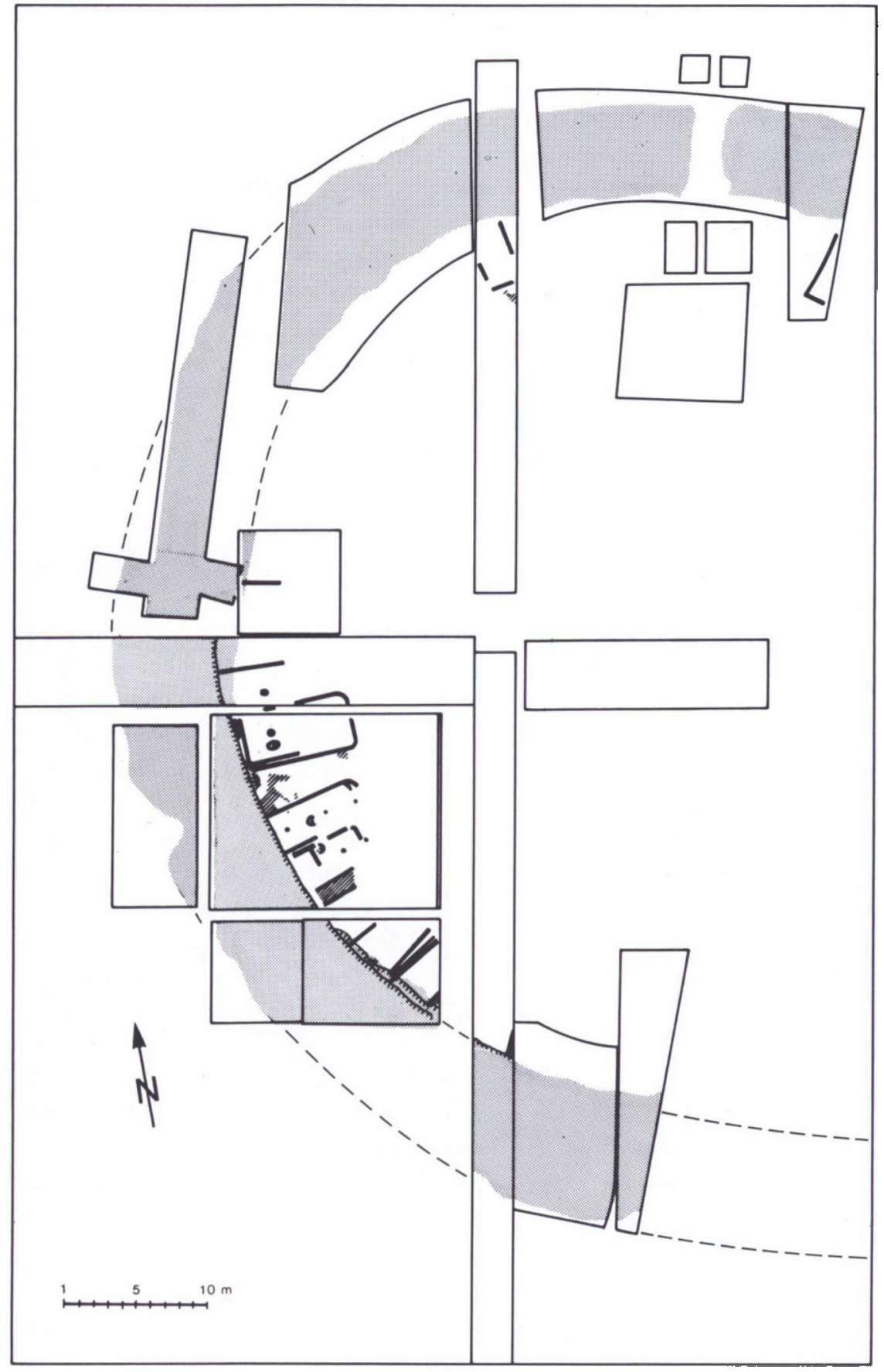




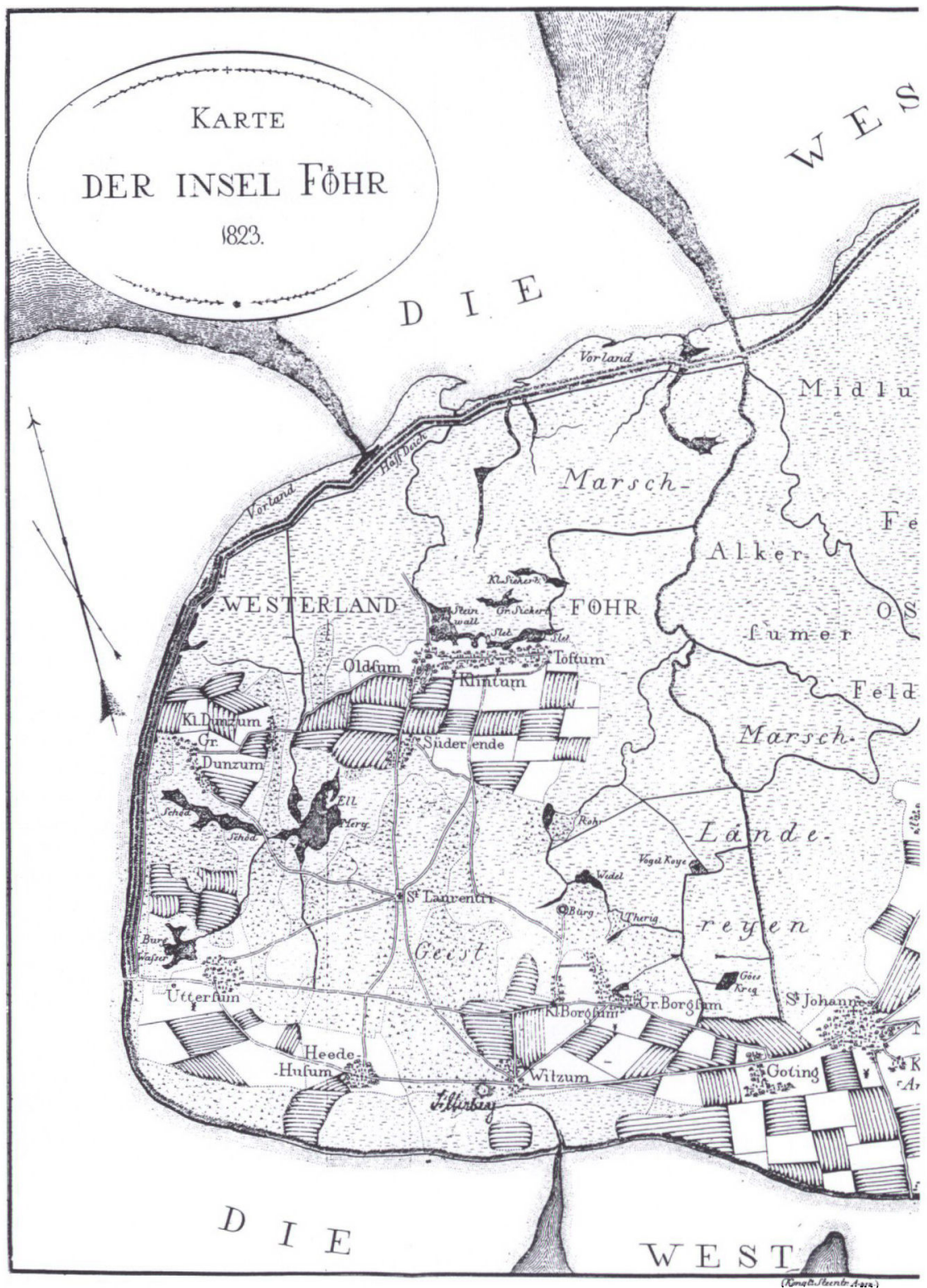

Voldstederne på For er angivet pd gamle kort. P\& dette udsnit af et kort over den vestlige del af For fra 1823 ses Lembecksborg angivet som "Burg" nord for Kl. Borgsum. Den folkelige overlevering satte voldstedet i forbindelse med drost Claus Lembeck. Den magtige mand skal her have ejet en borg, hvor han sogte tilfugt og blev belejret af kong Valdemar Atterdag.

Voldstedet Borreg là $i$ det sumpede dalstreg nordvest for Utersum. Kortet er her gengivet efter Fr. von Warnstedt: Die Insel Föhr und das Wilhelminen See-Bad, 1824. 
keramik på de nordfrisiske øer fortæller om, at både Sild, Før og Amrum blev inddraget $i$ denne handel, så Tinnumborg (2.) og Lembecksborg kan muligvis skyldes indflydelse udgået af dette samkvem. Disse kontakter er dog langtfra ensbetydende med, at postulatet om en frisisk indvandring til øerne i det 8.-10. århundrede er rigtigt. Tilflytningen kunne for så vidt udmærket være af langt ældre dato - eller også skyldes f.eks. en tidligere, i dag ukendt stammedannelse i Vestslesvig, Nedresaksen og Nordholland på grundlag af fælles sprog, religion, kulturforhold og indbyrdes handel omkring Kristi fødsel - et tredie folk mellem germanerne og kelterne? ?3 $^{33}$

\section{NOTER}

1. H.V. Gregersen, Det begyndte før Lindisfarne. Festskrift til Troels Fink. 1982, $47 \mathrm{ff}$;; samme, Den danske kongemagt ved vikingetidens begyndelse. Sønderjyske årbøger 1983, 18 ff.; samme, Kong Godfred og de nordfrisiske ringvolde. Sønderjysk månedsskrift 1985, 74 ff.; V. La Cour, Danske borganlæg til midten af det trettende århundrede. Bind 1. 1972, 43 ff.; P. La Baume, Die Wikingerzeit auf den Nordfriesischen Inseln. Jahrb. d. Nordfries. Ver. f. Heimatkunde und Heimatliebe 29, 1953, 137 ff.; H. Jankuhn, Ein Burgentyp der späten Wikingerzeit in Nordfriesland und sein historischer Hintergrund. ZSHG 78, 1954, 1 ff.; samme, Die Frühgeschichte. Geschichte Schleswig-Holsteins 3, 1957, 176 ff.; K. Kersten og La Baume, Vorgeschichte der nordfriesischen Inseln, 1958, $231 \mathrm{ff}$; $378 \mathrm{ff}$; $583 \mathrm{ff}$.

2. Kersten og La Baume (1958) 231 ff.; G. Kossack og O. Harck, Grabungen in der Archsumburg auf Sylt. Germania 51, 1973, 477 ff.; Kossack, Harck og J. Reichstein, Zehn Jahre Siedlungsforschung in Archsum auf Sylt. Ber. Röm.-Germ. Komm. 55, 1974, 261 ff.; Harck, Archäologische Untersuchungen in Wallanlagen Nordfrieslands. Ber. Röm.-Germ. Komm. 67, 1986, 362 ff.; Harck, Die Ausgrabungen in den kaiserzeitlichen Beringen Archsumburg, Tinnumburg und Trælbanken an der Westküste Schleswigs. 1987 (utrykt habilitations-disputats Kiel).

3. Kersten, Die Tinnumburg auf Sylt. Führer zu vor und frühgeschichtlichen Denkmälern 9, 1968, 232 ff., fig. på side 233; Kossack og Harck (1972), fig. 1; Harck (1986), fig. 1.

4. Kossack, Harck og Reichstein (1974); Harck (1987); Reichstein, Ausgrabungen in Alt-Archsum auf Sylt. Ber. Röm.-Germ. Komm. 67, 1986, 373 ff.

5. P. Schmidt-Eppendorf, Der Sylter Chronist Hans Kielholt. 1972; samme, Sylt. Memoiren einer Insel, 1977, $11 \mathrm{ff}$.

6. C. Danckwerth, Die Landkarten von Johannes Mejer, Husum, aus der neuen Landesbeschreibung der zwei Herzogtümer Schleswig und Holstein (Husum 1652, Nachdruck Hamburg-Bergedorf 1963) kort X-XI.

7. Harck (1987).

8. Kossack og Harck (1973), 482.

9. Harck (1986), 368, fig. 4.

10. K. Wilhelmi, Die vorrömische Eisenzeit zwischen Sieg und Mittelweser. Kleine Schr. Vorgesch. Seminar Marburg 8, 1981, 44 ff. med fig. 33.

11. Harck (1987).

12. Sidst omtalt: J. Lund, Nedgravede huse og kældre i ældre jernalder. hikuin 10, 1984, $57 \mathrm{ff}$.

13. Harck, Trælbanken ved Kærgård - et voldsted fra oldtiden. Nordslesvigske Museer 6, 1979, 29 ff.; Harck (1986), 371.

14. S. Jensen, Gårde fra vikingetid ved Gl. Hviding og Vilslev. Mark og montre 1986/87, 17 ff., fig. 17.

15. Harck (1986), 369; samme (1987), $490 \mathrm{ff}$.

16. Harck (1986), 369; Kersten og La Baume (1958), $231 \mathrm{ff}$. 
17. La Baume (1952/53), 138 ff. og 140.

18. H. Jankuhn (1957), $176 \mathrm{ff}$.

19. f.eks. La Baume (1952/53), Taf. 13,3; 30,2. Slesvig: H. Lüdtke, Die mittelalterliche Keramik von Schleswig. Ausgrabung Schild 1971-1975. Ausgrabungen in Schleswig. Berichte und Studien 4, 1985; Elisenhof: H. Steuer, Die Keramik. Elisenhof in Eiderstedt 3, 1979; Ribe: J. Nielsen, Middelalderbyen Ribe. 1985; Århus: H. H. Andersen, P.J. Crabb og H.J. Madsen, Århus Søndervold - en byarkæologisk undersøgelse. 1971.

20. Jankuhn (1954), $1 \mathrm{ff}$.

21. Kersten og La Baume (1958), $333 \mathrm{ff}$.

22. Jankuhn (1954), $3 \mathrm{ff}$.

23. H. Hinz, Motte und Donjon. Zur Frühgeschichte der mittelalterlichen Adelsburg. 1981. $67 \mathrm{ff}$.

24. Kersten og La Baume (1958), $461 \mathrm{ff}$.

25. Kersten og La Baume (1958), 219.

26. H. Handelmann, Die Bauernburgen auf den Nordfriesischen Inseln. ZSHG 3, 1873, $54 \mathrm{ff}$., især 65 ff.; A.L.J. Michelsen, Nordfriesland im Mittelalter. Falcks Staatsbürgerliches Magazin, VIII, $1828,97 \mathrm{ff}$. Urkunde 10.

27. Hinz (1981), 122 ff.; 133.

28. Jankuhn i: Kersten og La Baume (1958), 93.

29. Kersten og La Baume (1958), 532.

30. Kossack, Harck, Reichstein (udg.), Archsum auf Sylt, Teil 1. 1980. Sammenlign "Topographische Karte« med fig. 27 eller 50; »Borgrudera

31. Kersten og La Baume (1958), 172, fig. 36.

32. H. Neumann, Olgerdiget - et bidrag til Danmarks tidligste historie, 1982; W. Kramer, Die Datierung der Feldsteinmauer des Danewerks - Vorbericht einer neuen Ausgrabung am Hauptwall. Arch. Korrbl. 14, 1984, 343 ff., herimod: H.H. Andersen, Zum neuen Schnitt am Hauptwall des Danewerks. Arch. Korrbl. 15, 1985, 525 ff.; S. Hvass, Træeldiget. Vejle amts årbog 1984, 89 ff.

33. R. Hachmann, Kossack og H. Kuhn, Völker zwischen Germanen und Kelten, 1962. 